\title{
Evaluation of various rice (Oryza Sativa L.) genotypes for yield and yield characters under agro ecological conditions of Peshawar
}

\begin{abstract}
Investigation were undertaken at Agricultural Research Institute Tarnab (ARI) Peshawar during 2015 to study the performance of various rice genotypes for yield and yield characters under the agro-ecological conditions of Peshawar. The experiment was laid out in Randomized Complete Block Design (RCBD) with having three replications. The genotypes viz., Super Kernel, Kainat, Sadeeq, Komal, HS-98 and Fakhr e Malakand were investigated in the experiment. The agronomic data regarding; Days to panicle initiation, Panicle length $(\mathrm{cm})$, number of branches panicle-1, Plant height $(\mathrm{cm}), 1000$ seed weight $(\mathrm{g})$ and Grain yield $(\mathrm{kg}$ ha-1) was recorded. The analysis of data through revealed that maximum Days to panicle initiation (101.67) were noted in Super kernel while minimum (58.67) were recorded in Fakhr e Malakand , maximum panicle length $(26.86 \mathrm{~cm})$ was recorded in Super kernel while minimum $(22.92 \mathrm{~cm})$ was observed in Sadeeq, maximum number of branches panicle-1 (11.42) were noted in Komal while minimum (9.50) number of branches panicle-1 were reported in Kainat, maximum Plant height $(100.50 \mathrm{~cm})$ was reported in Super kernel while minimum $(83.17 \mathrm{~cm})$ Plant height was recorded in Fakhre Malakand, maximum 1000 seed weight $(44.90 \mathrm{~g})$ was reported in Sadeeq while minimum (43.22g) 1000 seed weight was noted in Kainat. Similarly, maximum Grain yield (9.30kg ha-1) was recorded in Komal while minimum (4.28 kg ha-1) was reported in Fakhr e Malakand. Hence It was concluded that genotypes: Super Kernel, Kainat, Sadeeq, Komal, HS-98 and Fakhr e Malakand produced maximum yield and were found most suitable for the agro climatic conditions of Peshawar.
\end{abstract}

Keywords: rice genotypes, yield and yield characters
Volume 8 Issue 6 - 2018

\author{
Muneeb Khan,' Sami Ullah Khan,' Abdur \\ Rehman, ${ }^{2}$ Kamran Khan, ${ }^{3}$ Muhammad \\ Mehran Anjum, ${ }^{3}$ Nawab Ali, ${ }^{3}$ Kamal Shah, ${ }^{3}$ \\ Saifullah ${ }^{3}$ \\ 'Department of Agricultural Sciences, University of Haripur, \\ Khyber Pakhtunkhwa, Pakistan \\ ${ }^{2}$ Agriculture Research Institute Tarnab, Peshawar, Pakistan \\ ${ }^{3}$ Department of Agronomy, The University of Agriculture, \\ Khyber Pakhtunkhwa, Peshawar, Pakistan
}

Correspondence: Muneeb Khan, Department of Agricultural Sciences, University of Haripur, Khyber Pakhtunkhwa, Pakistan, Email muneebkhanagro@gmail.com

Received: November 16, 2017 | Published: December 19, 2018

\section{Introduction}

Rice (Oryza sativa L.) is the world's most important food crop belongs to Poaceae. It serves as the staple food for more than half of the globe's population. ${ }^{1}$ Worldwide, it is grown on an area of 166.1 million hectares with yield of 745.2 million tonnes. ${ }^{2}$ Rice is the second leading cereal crop of Pakistan after wheat with 2.3 million hectares area planted and 5.5 million tones production, In which Punjab 2481 tons, Sindh 2617 tons, Khyber Pakhtunkhwa 111.90 tons and Balochistan 587 tons shear of production during 2013-14. ${ }^{3}$ In the Punjab and Sindh provinces, world's famous Basmati rice is grown while in the Khyber Pakhtunkhwa province northern regions cool tolerant rice cultivars and landraces are planted. Long grain IRRI type heat stress tolerant rice cultivars are planted in the southern areas of Khyber Pakhtunkhwa and the province of Balochistan. ${ }^{4}$ Rice accounts for $3.2 \%$ in the value added in agriculture and $0.7 \%$ of GDP. During July - March 2014-15. Rice export eared foreign exchange 1.53 billion US dollar. During 2014-15, rice was shown on an area of 2891 thousand hectares showing an increase of $3.6 \%$ over last year's area of 2789 thousand hectares. Rice recorded highest ever production at 7005 thousand Tons, showing a growth of $3.0 \%$ over corresponding period of last year's production which was 6798 thousand tons. Rice production increased due to more area brought under cultivation, timely availability of irrigation water and more acreage under high yielding Hybrid rice varieties.

\section{Economic importance of rice for Pakistan}

Rice is the second most important crop which brings economic prosperity of the growers as well as earns billions of rupees through its export for country. Pakistani fine rice commonly known as Basmati is world famous and enjoys monopoly in the international market, due to its quality characteristics, strong aroma, slender and long kernel, gelatinization, temperature and high degree of grain elongation on cooking. However, the grain yield of basmati rice varieties is very low. In order to remain in the International market, we have to further improve the quality as well as yield of basmati varieties. Rice plays a pivotal role in the agro-based and occupies a prominent position in agricultural economy of Pakistan. Rice is a high valued cash crop and is also a major export item. It accounts for 5.7 percent of the total value added in agriculture and 1.3 percent to GDP. Production of rice during 2004-05 is provisionally estimated at 4991 thousand tons, which is 2.9 percent higher than last year. Rice was cultivated on an area of 2503 thousand hectares, showing an increase of 1.7 percent over last year. The production of rice is quite low compared to other rice growing country of the world, in spite of high yielding varieties and increased the use of fertilizer. The yield level of high yielding varieties is plateauing in recent year. To meet the demand of increasing population and maintain this self sufficiency the present production level need to be increased up to 140 million tons by 2025 which can be achieved only by increasing the rice production by over 
2 million tons per year in coming decade (Anonymous, 2005). This has to be done against the backdrop of declining natural resource base such as land, water, labor and other inputs and without adversely affecting the quality of environment.

Rice grain yield is a quantitative polygenic character and highly influenced by environment. Extent and significance of association of yield with yield components should be considered, while determining the selection criteria of germplasm on the basis of available genetic variation. ${ }^{5}$ The success of breeding program also depends upon the amount of genetic variability present in the population and extent to which the desirable traits are heritable. Different morphological traits play very important role for more rice production with new plant type characteristics associated with the plant yield. ${ }^{6}$ Phonological properties of rice also associated with the yield potential of the different rice varieties for the selection of the best varieties that further involved in rice breeding program. ${ }^{7}$ Thousands rice cultivars have been evolved through selection from the cultivated material many centuries ago, which are well adapted to the local environments. Many of those rice cultivars having good quality characteristics and higher yield potential under biotic and abiotic stress environments. Since the dawn of civilization, thousands of locally adapted genotypes of aromatic rice have evolved through human selection. ${ }^{8}$ Keeping in view the above facts, the present investigation entitled "Evaluation of various rice (oryza sativa L.) Genotypes for yield and yield characters under agro ecological conditions of Peshawar" was carried out at ARI Tarnab Peshawar" to fulfill the following objective;

\section{Objective}

a. To evaluate different rice genotypes for yield and yield components

b. To find out suitable high yielding genotype for Peshawar region

\section{Materials and methods}

\section{Experiment site}

The experiment was conducted at Agricultural Research Institute (ARI) Tarnab Peshawar during 2015.

\section{Land preparation}

The land was prepared by three deep repeated plough and level the land. The filed were divided into sub plots. Now the field is ready and then seeds are sown. Row to row distances was kept $30 \mathrm{~cm}$.

\section{Genotypes of rice}

Six Rice varieties viz. Super kernel, Kainat, Sadeeq, Komal, HS-98 and Fakhr e Malakand were used in the current research investigation.

\section{Fertilizers application}

The application of fertilizer were keep constant for all genotypes, DAP is applied as basal dose, while Urea were applied 30 days after sowing.

\section{Experimental design}

The experimental was laid out in Randomized Complete Block Design (RCBD) with split plot arrangements having three replications.

\section{Parameters}

The following parameters were studied during experiment.

\section{A. Days to panicle initiation}

The days to panicle initiation was recorded in all genotypes at the time of $50 \%$ emergence of panicle and recorded the data. The data were converted into mean.

\section{B. Panicle length $(\mathrm{cm})$}

The panicle length was measured randomly selected plants all genotypes with the help of measuring tape and recorded the data. Then means was computed the mean.

\section{Number of branches panicle ${ }^{-1}$}

In all genotypes number of branches panicle ${ }^{-1}$ was counted in randomly selected plants. Then means was computed from sum.

\section{Plant height (cm)}

Plant height $(\mathrm{cm})$ was measured in randomly selected plants all genotypes with the help of measuring tape and record the data. Then mean was calculated.

\section{E. 1000 seed weight (g)}

1000 seed weight in all genotypes was measure with help of electric balance.

\section{F. Grain yield $\left(\mathrm{kg} \mathrm{ha}^{-1}\right)$}

The grain yield per plot was recorded by harvesting rice plants into $\mathrm{kg} \mathrm{ha}^{-1}$.

\section{Statistical analysis}

The data noted on various parameters were subjected to the analysis of variance (ANOVA) method to find out the variance between all genotypes. In cases where variances were initiate significant, averages were matched for variances using least significant variance (LSD) test. Statistical analysis software (Statistix 8.1) was applied for computing both the ANOVA and LSD (Steel and Torrie, 1998).

\section{Results and discussion}

The results presented in this manuscript were obtained from an experiments conducted during 2015 at ARI Tarnab Peshawar, the objective of this experiments was to study the "Evaluation of various rice (Oryza sativa L.) Genotypes for yield and yield characters under the agro ecological conditions of Peshawar". The results regarding days to panicle initiation, panicle length, branches panicle ${ }^{-1}$, plant height, 1000 seeds weight and grain yield are presented and discussed in following.

\section{Days to panicle initiation}

The data regarding days to panicle initiation are given in Table 1. The analysis of the data showed that all genotypes are significantly different with regard to days to panicle initiation. The maximum (101.67) days to panicle initiation was recorded in Super Kernel genotype followed by Kainat genotype who take (83.67) days to panicle initiation, whereas minimum (58.67) days to panicle initiation was observed in Fakhr e Malakand. This might be due to its early maturing genetic ability. The results are in agreement with. ${ }^{9,10}$ reported that translation time, water and soil condition, planting and sowing method affect days to panicle initiation, while Jamal et al., ${ }^{11}$ attributed the variation of panicle initiation to genetic variability of genotype. 


\section{Panicle length (cm)}

The data regarding to panicle length are presented in Table 1. The analysis of data shows significant difference among the genotype. There results that maximum $(26.86 \mathrm{~cm})$ panicle length was recorded in Super Kernel genotype followed by Fakhr e Malakand genotype having $(25.93 \mathrm{~cm})$ panicle length, whereas minimum $(22.95 \mathrm{~cm})$ panicle length was observed in HS-98 genotype. The results are in line with Sultana et al., ${ }^{12}$ The variation in Panicle length of various genotypes is might be due to the variation in genetic makeup of different genotype. ${ }^{13}$ also reported variation in different genotypes.

Table I Days to panicle initiation, Panicle Length $(\mathrm{cm})$

\begin{tabular}{|c|c|c|c|}
\hline S. no. & Varieties & $\begin{array}{l}\text { Days to panicle } \\
\text { initiation }\end{array}$ & Panicle length $(\mathrm{Cm})$ \\
\hline 1 & $\begin{array}{l}\text { Super } \\
\text { kernel }\end{array}$ & $101.67 \mathrm{~A}$ & $26.86 \mathrm{~A}$ \\
\hline 2 & Kainat & $83.67 \mathrm{~B}$ & $24.83 \mathrm{ABC}$ \\
\hline 3 & Sadeeq & $68.33 \mathrm{CD}$ & $22.92 \mathrm{C}$ \\
\hline 4 & Komal & $71.33 \mathrm{C}$ & $23.79 \mathrm{BC}$ \\
\hline 5 & H.S-98 & $70.33 \mathrm{C}$ & $22.95 \mathrm{C}$ \\
\hline 6 & $\begin{array}{l}\text { Fakhr e } \\
\text { Malakand }\end{array}$ & $58.67 \mathrm{D}$ & $25.93 \mathrm{AB}$ \\
\hline $\begin{array}{l}\text { LSD } \\
(0.05)\end{array}$ & & 10.43 & 2.3 \\
\hline
\end{tabular}

The means following similar English letters did not differ significantly at $\mathrm{p} \leq 0.05$

\section{Branches panicle ${ }^{-1}$}

Differences in branches panicle- ${ }^{1}$ in various genotype of rice are presented in Table 2. It is evident from the table that the branches panicle $^{-1}$ were found significantly different among the genotypes. There results that maximum (11.417) branches panicle ${ }^{-1}$ was recorded in Komal genotype followed by Sadeeq genotype having (11.083) branches panicle ${ }^{-1}$, whereas minimum $(9.50)$ branches panicle $^{-1}$ was observed in Kainat genotype. The results are supported by. ${ }^{11}$

\section{Plant height $\mathbf{( c m )}$}

Differences in plant height in various genotype of rice are presented in Table 2. It is evident from the table that the plant height was found significantly different among the genotypes. The result shows that maximum $(100.50 \mathrm{~cm})$ plant height was observed in Super kernel genotype followed significantly by kainat genotype having $(100.17 \mathrm{~cm})$ plant height recorded, whereas minimum $(83.17 \mathrm{~cm})$ plant height was observed in Fakhr e Malakand genotype. The variation in plant height of different genotypes is may be attributing to different climatic requirements of various genotypes. ${ }^{14}$ also concluded that there is various climatic requirements of each genotype. The results are in line with (Latif et al., 2007).

\section{Seed weight (g)}

The data regarding days to 1000 seed weight are presented in Table 3. The analysis of the data shows that 1000 seed weights in all genotypes are significantly different. The maximum (44.90g) 1000 seed weight was recorded in Sadeeq genotype followed by Fakhr e Malakand genotype who produce $(44.70 \mathrm{~g}) 1000$ seed weights, whereas minimum (41.87g) 1000 grain weights was observed in genotype Komal. The results are in agreement with ${ }^{15}$ who reported variation in 1000 grain yield of different genotypes. They also attribute this variation to the variability in genetic makeup and different climatic requirements.

\section{Grain yield (kg/ha)}

Differences in grain yield in various genotype of rice are presented in Table 3. It is evident from the table that the grain yield $(\mathrm{kg} / \mathrm{ha})$ was found significantly different among the genotypes. There result shows that maximum $(4282.6 \mathrm{~kg} / \mathrm{ha})$ Grain yield was recorded in Sadeeq genotype followed by Komal genotype having (4072.8kg/ha) Grain yield, whereas minimum $(1885.3 \mathrm{~kg} / \mathrm{ha})$ Grain yield was observed in Fakhr e Malakand genotype. The results are in line with. ${ }^{11,16}$ reported highly significant variation in grain yield $(\mathrm{kg} / \mathrm{ha})$ of different genotypes. Other factors i.e. Soil fertility, plant nutrients translocation and weather condition might also responsible. ${ }^{17-25}$

Table 2 Plant Height $(\mathrm{Cm})$, Number of Branches Pancicle-I

\begin{tabular}{|c|c|c|c|}
\hline S. no. & Varieties & $\begin{array}{l}\text { Plant } \\
\text { height } \\
(\mathrm{Cm})\end{array}$ & $\begin{array}{l}\text { Number of branches } \\
\text { pancicle }^{-1}\end{array}$ \\
\hline I & $\begin{array}{l}\text { Super } \\
\text { kernel }\end{array}$ & $100.50 \mathrm{~A}$ & $10.88 \mathrm{~A}$ \\
\hline 2 & Kainat & $100.17 \mathrm{~A}$ & $9.50 \mathrm{~A}$ \\
\hline 3 & Sadeeq & $91.92 \mathrm{~B}$ & $11.08 \mathrm{~A}$ \\
\hline 4 & Komal & 89.67 B & $1 \mathrm{I} .42 \mathrm{~A}$ \\
\hline 5 & H.S-98 & 89.42 B & $10.83 \mathrm{~A}$ \\
\hline 6 & $\begin{array}{l}\text { Fakhr e } \\
\text { Malakand }\end{array}$ & $83.17 \mathrm{C}$ & $10.25 \mathrm{~A}$ \\
\hline LSD (0.05) & & 4.73 & 2.01 \\
\hline
\end{tabular}

The means following similar English letters did not different significantly at $\mathrm{p} \leq 0.05$

Table 31000 Seed weight, Grain yield

\begin{tabular}{llll}
\hline S. no. & Varieties & $\begin{array}{l}\text { I 000 Grains } \\
\text { weight }\end{array}$ & $\begin{array}{l}\text { Grain yield } \\
\text { kg.ha' }\end{array}$ \\
\hline I & Super Kernal & $43.92 \mathrm{~A}$ & $4040.5 \mathrm{~A}$ \\
2 & Kainat & $43.22 \mathrm{~A}$ & $2253.5 \mathrm{BC}$ \\
3 & Sadeeq & $44.90 \mathrm{~A}$ & $4282.6 \mathrm{~A}$ \\
4 & Komal & $41.87 \mathrm{~A}$ & $4072.8 \mathrm{~A}$ \\
5 & H.S-98 & $44.23 \mathrm{~A}$ & $3594.5 \mathrm{AB}$ \\
6 & $\begin{array}{l}\text { Fakhr e } \\
\text { Malakand }\end{array}$ & $44.70 \mathrm{~A}$ & $1885.3 \mathrm{C}$ \\
LSD & & 3.55 & 2.228 \\
\hline
\end{tabular}

\section{Acknowledgments}

None.

\section{Conflicts of interest}

The authors declared there is no conflicts of interest. 


\section{References}

1. Khan AS, M Imran, M Ashfaq. Estimation of Genetic Variability and Correlation for Grain Yield Components in Rice (Oryza sativa L.). American-European J Agric Environ Sci. 2013;6:585-590.

2. Anonymous. Agricultural Statistics of Pakistan. Government of Pakistan, Ministry of food, Agriculture and livestock, Islamabad: 2013.

3. Anonymous. Agricultural Statistics of Pakistan. Government of Pakistan, Ministry of food, Agriculture and livestock, Islamabad: 2014.

4. Sharifi P, D Hamid, M Ali et al. Genetic and genotype $\times$ environment interaction effects for appearance quality of rice. Agricultural Sciences in China. 2009;8(8):891-901.

5. Habib SH, MK Bashar, M Khalequzzaman, et al. Genetic analysis and morpho-physiological selection criteria for traditional biroin Bangla desh rice germplasm. J Biol Sci. 2005;5:315-318.

6. Yu H G, FQ Zhu, CL Wang. Preliminary report of the application of the high-yielding techniques of SRI in single cropping hybrid rice. Hybrid Rice. 2008;19:33-35.

7. Shahidullah SM, MM Hanafi, M Ashrafuzzaman, et al. Phenological characters and genetic divergence in aromatic rices. African $J$ Biotech. 2009;8:3199-3207.

8. Singh RK, PL Gautam, S Saxena et al. Scented Rice Germplasm Consevation, Evaluation and Utilization. In: Aromatic rice, Oxford and IBH publishing Co. Pvt. Ltd. New Delhi, India: 2000. 107-133 p.

9. Ashfaq M, Khan AS, Khan SHU, et al. Association of various morphological traits with yield and genetic divergence in rice (Oryza Sativa L.). Int J Agric Biol. 2012;14:55-62.

10. Hussain S, M Ramzan, M Aslam, et al. Effect of Various Stand Establishment Method on Yield and Yield Components of Rice. Proceedings of the International Seminar on Rice Crop. 2005;212-220.

11. Jamal, Ifftikhar H, M Khalil, et al. Genetic variation for yield and yield components in rice. ARPN Journal of Agricultural and Biological Science. 2009;4(6):60-64.

12. Sultana T, R Islam, Md S Newaz, et al. Performance evaluation of two rice varieties under different levels of nacl salinity stress. Bangl Res Pub J. 2014;10(2):186-195.

13. Cha-um S, P Vejchasarn, C Kirdmanee. An Effective Defensive Response in Thai Aromatic Rice Varieties (Oryza sativa L. spp. indik) to Salinity. $J$ Crop Sci Biotech. 2005;(4):257-264.
14. Rabbani M A, MS Masood, ZK Shinwari et al. Genetic analysis of basmati and non-basmati Pakistani rice (Oryza sativa L.) cultivars using microsatellite markers. Pak J Bot. 2010;42(4):2551-2564.

15. Zahid AM, M Akhtar, M Sabar, et al. Interrelation-ship among Yield and Economic Traits in Fine Grain Rice. Proceedings of the International Seminar on Rice Crop. 2005;10(2-3):.Rice Research Institute, Kala Shah Kau, Pakistan.2005;21-24.

16. Tahir M, D Wadan, A Zada. Genetic Variability of Different Plant Yield Characters in Rice. Sarhad J Agric. 2002;18(2)

17. Ashfaq M, Khan AS, Khan SHU, et al. Association of various morphological traits with yield and genetic divergence in rice (Oryza Sativa L.). Int J Agric Biol. 2012:14:55-62.

18. Ashfaq M, MS Shaukat, M Akhter, et al. Comparison of fungal diversity of local and exotic rice (Oryza Sativa L.) Germplasm for their seed health. J Anim Plant Sci. 2015;25(5):1349-1357.

19. Babu VR, K Shreya, KS Dangi, et al. Evaluation of Popular Rice (Oryza sativa L.) Hybrids for Quantitative, Qualitative and Nutritional Aspects. International Journal of Scientific and Research Publications. 2013;3(1):1-8.

20. Fagerian K, OP De Morais, AB Dos Santos. Nitrogen use efficiency in upland rice genotypes. Journal of Plant Nutrition. 2010;33(11):16961711.

21. Fasahat P, M Kharidah, A minah, et al. Genotype and environment assessment for grain quality traits in rice. Int J Agri and Bio. 9(2):71-82.

22. Nejad G, Mohammadi, RK Singh, et al. Evaluation of salinity tolerance in rice genotypes 2010. International Journal of Plant Production. 2010;4(3): 1735-8043.

23. Pervaiz ZH, MA Rabbani, ZK Shinwari, et al. Assessment of genetic variability in rice (oryza sativa L.) Germplasm from pakistan using rapd markers. Pak J Bot. 2010;42(5):3369-3376.

24. SultanaT, R Islam, M Shah Newaz Chowdhury, et al. Performance evaluation of two rice varieties under different levels of Nacl salinity stress, Ban, ResPub J. 2014;10(2):186-195.

25. Tripathi K, A Saxena. Evaluation of local, improved and hybrid varieties of rice for insect pest. International Journal of Scientific and Research Publications. 2013;3(11):1-4. 